\title{
A new strategy for synthesis of microspheres amphiphilic block copolymer based on Epichlorohydrin and N-viny-2-pyrrolidone induced by an ecologic clay catalyst called Maghnite- $\mathrm{H}^{+}$ (Algerian MMT)
}

\author{
Rahmouni Abdelkader*, Bendaho Djelloul, Ferrahi Mohammed Issam, Belbachir Mohammed \\ Département of chemistry, laboratory of polymer chemistry Faculty of sciences, Oran university \\ *Corresponding author E-mail: ramaek23@yahoo.fr
}

\begin{abstract}
Biodegradable copolymer microsphere poly (ECH-co-NVP) was synthesized by a ring-opening polymerization process of Epichlorohydrin and N-vinyl-2-pyrrolidone.The copolymerization of Epichlorohydrin (ECH) and N-vinyl-2pyrrolidone (NVP) catalyzed by Maghnite- $\mathrm{H}^{+}\left(\mathrm{Mag}-\mathrm{H}^{+}\right)$was investigated. The effect of some factors such as the amount of the catalyst $\left(\right.$ Maghnite- $\left.\mathrm{H}^{+}\right)$and the temperature of reaction. It was found that the copolymerization rate increased with increase in the temperature and the proportion of catalyst, and it was larger in nonpolar solvents. The product was characterized by various technic characterizations such as FTIR and 1H-NMR.
\end{abstract}

Keywords: Epichlorohydrin, $N$-vinyl-2-pyrrolidone, amphiphilic block, maghnite- $H^{+}$, microspheres, H-NMR spectroscopy, ring opining polymerization.

\section{Introduction}

In recent years, polymers based on Epichlorohydrin and N-vinyl-2-pyrrolidone have received increasing attention [1-2]. Polymerization of this monomer via ring opening of the epoxy group has been subjected only in few papers [3]. Epichlorohydrin is a colorless liquid with a characteristic chloroform-like odor that is manufactured using chlorine, propylene and milk of lime as raw materials. Epichlorohydrin is used in the production of polyamide resins for ion exchange [4], the water treatment and paper industries [5], flame retardants, quaternary amines and in the production of Zeospan, a specialty polyether rubber used in automobiles [6]. N-Vinyl-2-pyrrolidone (NVP) is either caustic stabilized

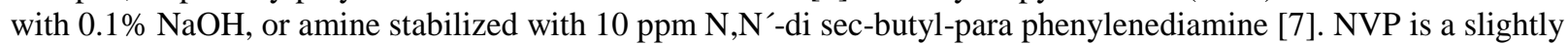
to moderately yellow heterocyclic [8], reactive vinyl monomer made from the reaction of acetylene and N-vinyl-2pyrrolidone [9]. The inherent properties of high polarity, low toxicity, water solubility, chemical stability and pseudocationic activity are imparted to its photopolymers and copolymers [10].

Montmorillonites have both Brönsted and Lewis acid sites and when exchanged with cations having a high charge density, such as protons, they produce highly-active catalysts for acid-catalyzed reactions [11]. Modified (actived) clays also have been used in other applications. These applications include adsorbents, rheological control agents, paints, grease, cosmetics, personal care products, oil well drilling fluids, etc [12] .Among the clay minerals, smectites, especially Montmorillonite, have been extensively used to prepare organ clays because of its excellent properties, such as high cation exchange capacity, swelling behavior, adsorption properties and large surface area[13].According to (Belbachir et all 2001) Maghnite- $\mathrm{Na}^{+}$and Maghnite- $\mathrm{H}^{+}$have been prepared and used in an industrial scale. These clay minerals swell in water into a manner similar to smectites, and have interlayer charge densities higher than that of smectites [14]. Unlike natural clay minerals, they have high crystallinity, controllable composition and fewer impurities [15]. For this reasons, the use of such modified Maghnite as host materials is expected to be more advantageous than the use of raw natural clay minerals $\left(\right.$ Maghnite- $\left.\mathrm{Na}^{+}\right)[16]$.Biodegradable polymers should non-toxic, capable of maintaining good mechanical integrity until degraded, and capable of controlled rates of degradation[17]. A goal is not to illicit the immune response, and the products of degradation also need to be non-toxic. Biodegradable polymers have been extensively investigated for temporary therapeutic applications such as surgical sutures, bone fracture internal fixation devices, drug delivery systems, as well as tissue engineering scaffolds [18].In recent years, some researches are focused on using new modified natural clays as catalysts or initiators for polymerization of vinylic and hetero-cyclic 
monomers [19,20,21]. In the present study Epichlorohydrin (ECH) copolymerized with N-Vinyl-2-pyrrolidone (NVP) was targeted, which would combine the advantages of ECH and NVP to broaden the field of application. The properties of block copolymers depend on the co-monomer composition and also on the sequence distribution of the constituent co-monomers. In this work, we would like to report a new and efficient ecologic catalyst which is a protonated organically-modified nanoclay $\left(\right.$ Maghnite- $\left.\mathrm{H}^{+}\right)$in order to prepare microsferes amphiphilic block copolymer based on (Epichlorohydrin and N-vinyl-2-pirolidone) used in devices medicals [22]. The product is very soluble in comments organics solvent such as chloroform, dichloromethane....etc and can be extracted from the reaction media easily. . Techniques such as $1 \mathrm{H}$ NMR, IR, were used to characterize the products of the reaction.

\section{Experimental parts}

\subsection{Materials}

1) The monomers (NVP, ECH) (Aldrich 99\%) was purified by fractional distillation under reduced pressure, was used as received. Raw-Maghnite, Algerian Montmorillonite clay was procured from "BENTAL" (Algerian Society of Bentonite).

2) Dichloromethane (DCM) was washed successively with conc. sulfuric acid, distilled water, $5 \%$ aqueous Sodium hydroxide, and distilled and dried over anhydrous calcium chloride. DCM was distilled (by $40^{\circ} \mathrm{C}$ ) from calcium hydride and stored.

3) Methanol was used as received.

4) $\quad 0.05 \mathrm{M}, 0.10 \mathrm{M}, 0.15 \mathrm{M}, 0.20 \mathrm{M}, 0.25 \mathrm{M}, 0.30 \mathrm{M}$ and $0.35 \mathrm{M}$ sulfuric acid treatment solutions were used to prepare

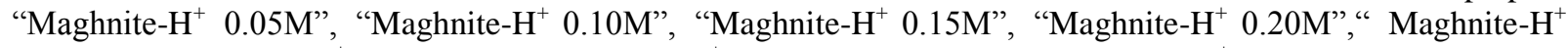
$0.25 \mathrm{M}$ ", “ Maghnite- $\mathrm{H}^{+} 0.30 \mathrm{M}$ " and "Maghnite- $\mathrm{H}^{+}$0.35M" respectively. "Maghnite- $\mathrm{H}^{+} \mathrm{XM}$ ", the acid form of "raw-Magnate", is prepared by shaking the raw material (raw-Maghnite-Na) with a solution of sulfuric acid at room temperature until saturation is achieved over a two day period, The cation-exchanged clay was filtered, resuspended in deionized water continuously until no sulfate ions were detected in the filtrate by $\mathrm{BaCl}_{2}$; isolated by filtration; dried in an oven at $105^{\circ} \mathrm{C}$ and then finely ground. The clay cation exchange capacity (CEC) was found to be $84 \mathrm{mEq} / 100 \mathrm{~g}$ of dried clay.

\section{Results and discussion}

\subsection{Figures, photos, tables, and equations}

Maghnite- $\mathrm{H}^{+}$were prepared by a method similar to that described by Belbachir et al. Raw-Maghnite $-\mathrm{Na}^{+}(20 \mathrm{~g})$ was crushed for $20 \mathrm{mn}$ using a prolabo ceramic balls grinder. It was then dried for $2 \mathrm{~h}$ at $105^{\circ} \mathrm{C}$. The Maghnite- $\mathrm{H}^{+}$was placed in an Erlenmeyer flask together with $500 \mathrm{ml}$ of distilled water. The Maghnite/water mixture was stirred using a magnetic stirrer and combined with $0.25 \mathrm{M}$ sulfuric acid solution, until neutralization was achieved over 2 days at room temperature, the mineral was then washed with distilled water to become sulfate free and then dried at $150^{\circ} \mathrm{C}$. The Table-1 show elementary compositions of Protons exchanged samples.

Table 1: Show chemical composition of Mag- $\mathrm{H}^{+}$(catalyst)

\begin{tabular}{|c|c|c|c|c|c|c|c|c|c|c|c|}
\hline \multirow[t]{2}{*}{ Sample } & \multicolumn{11}{|c|}{ Chemical composition } \\
\hline & $\mathrm{SiO}_{2}$ & $\mathrm{Al}_{2} \mathrm{O}_{3}$ & $\mathrm{Fe}_{2} \mathrm{O}_{3}$ & $\mathrm{CaO}$ & $\mathrm{MgO}$ & $\mathrm{Na}_{2} \mathrm{O}$ & $\mathrm{K}_{2} \mathrm{O}$ & $\mathrm{TiO}_{2}$ & $\mathrm{SO}_{3}$ & As & PAF \\
\hline Maghnite raw & 69.3 & 14.67 & 1.16 & 0.30 & 1.07 & 0.50 & 0.79 & 0.16 & 0.91 & 0.05 & 11 \\
\hline Maghnite- $\mathrm{H}^{+}$ & 71.7 & 14.03 & 0.71 & 0.28 & 0.80 & 0.21 & 0.77 & 0.15 & 0.34 & 0.01 & 11 \\
\hline
\end{tabular}

\subsection{Catalyst structure}

Various methods of analysis, such as ${ }^{27} \mathrm{Al}$ and ${ }^{29} \mathrm{Si}$ MAS NMR, show that "Maghnite" is montmorillonite sheet silicate clay (yahiaoui et al 2003). The elementary analysis of selected samples obtained using XRF and co-monomer conversions obtained from the reaction of $0,41 \mathrm{~g}(5 \%)$ of each sample with 3,71g of Epichlorohydrin and 4,5g of $\mathrm{N}$ vinyl-2-pyrrolidone for 4 hours in a bulk polymerization at $20^{\circ} \mathrm{C}$.

It is necessary to report that the best value of Epichlorohydrin and N-vinyl-2-perilidone conversion is obtained with "Maghnite- $\mathrm{H}^{+} 0.25 \mathrm{M}$ ". We thus selected this sample to study the effect of catalyst proportions and temperature on 
Epichlorohydrin and N-vinyl-2-perilidone polymerization. Acid treatment of "Raw-Maghnite" caused a reduction in octahedral $\mathrm{Al}_{2} \mathrm{O}_{3}$ content with an increase in the proportion of silica $\left(\mathrm{SiO}_{2}\right)$ observed. The copolymer yield decrease implies that the Maghnite original structure was not preserved (destroyed) after acid treatment at a concentration $\geq 0.25$ M.

The ${ }^{27} \mathrm{Al}$ MAS NMR spectra of both Raw-Maghnite and Maghnite- $\mathrm{H}^{+}-0.25 \mathrm{M}$ (Fig. 1) show Aluminum in two tetrahedral environments, with resonances centered at 60 and $68 \mathrm{ppm}$, in addition to the main contribution from the octahedral aluminum at 2.9ppm. These values and assignments concur with those published in the literature [23, 24].

The ${ }^{29} \mathrm{Si}$ MAS NMR spectra for the Raw-Maghnite and Maghnite- $\mathrm{H}^{+} 0.25 \mathrm{M}$ are shown in Fig 2. The dominant resonance at - $93.5 \mathrm{ppm}$ corresponds to Q3 (OAl) units, i.e. $\mathrm{SiO}_{4}$ groups crosslinked in the tetrahedral sheets with no aluminum in the neighboring tetrahedral [25]. The resonance at $-112 \mathrm{ppm}$ corresponds to three-dimensional (3D) silica with no aluminum present and is generally labeled Q4 (OAl) [26, 27. 28]

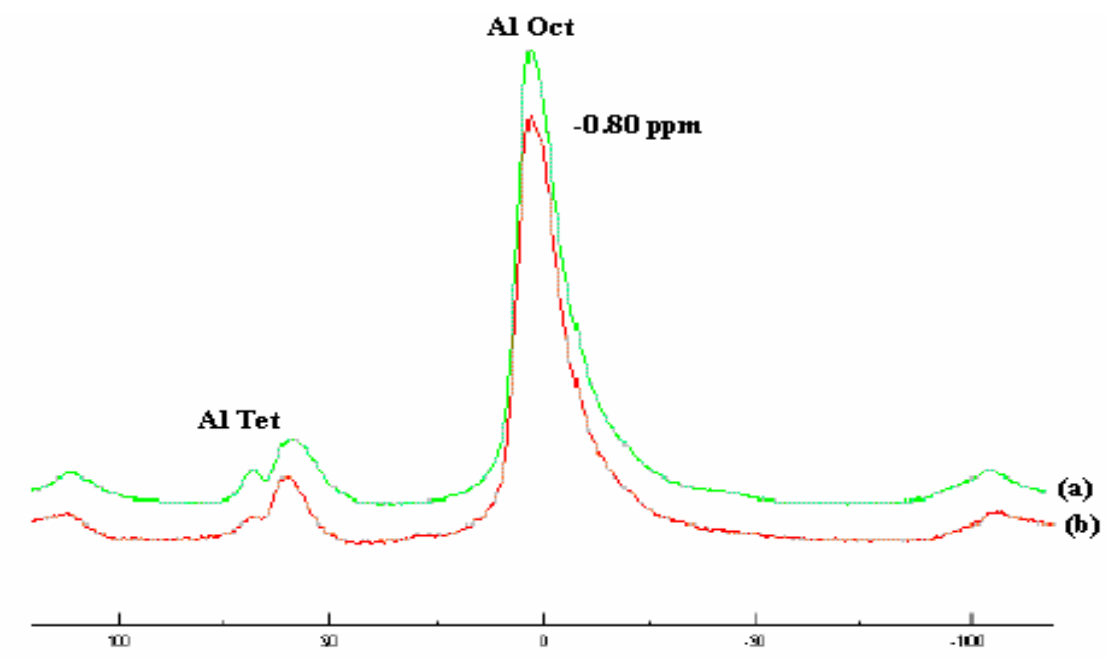

Fig. 1: ${ }^{27} \mathrm{Al}$ MAS NMR spectra of (a) "Maghnite -Raw" and (b) "Maghnite $\mathrm{H}^{+}$" $0.25 \mathrm{M}$

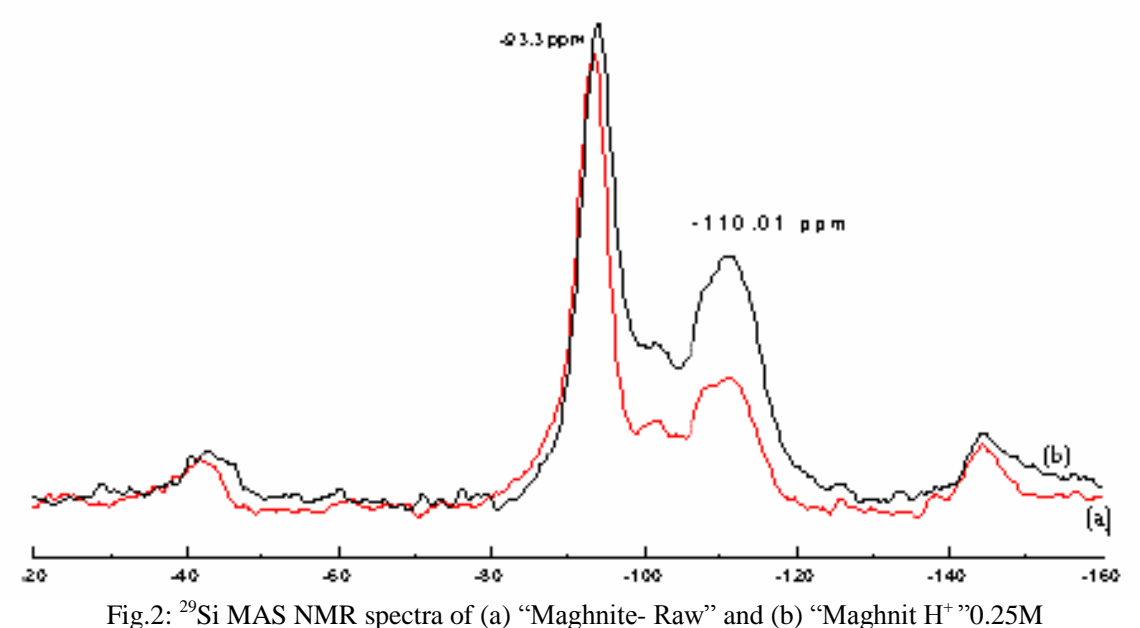

\subsection{Procedure and product characterization}

The Poly (Epichlorohydrin-co-N-Vinyl-2-pyrrolidone) copolymers were prepared by bulk polymerization in an Erlenmeyer flask of $125 \mathrm{ml}$. By mixture of 4,5g of (N-vinyl-2-pyrrolidone), with 3,71g of (Epichlorohydrin) and $0,41 \mathrm{~g}$ $(5 \%)$ of catalyst $\left(\right.$ Maghnite- $\left.\mathrm{H}^{+}\right)$. The catalyst was dried in a muffle oven at $120^{\circ} \mathrm{Cover}$ night and then transferred to a vacuum desiccator containing $\mathrm{P}_{2} \mathrm{O}_{5}$ the mixture was stirred with a magnetic stirrer at room temperature for 4 hours. At the end of the reaction the resulting mixture was filtered to remove the clay and then slowly added to methanol with stirring and then the polymer was dried under vacuum at room temperature for $24 \mathrm{~h}$. a quantity of ethanol was then added to eliminate Maghnite- $\mathrm{H}^{+}$and oligomers. The resulting mixture was filtered to remove the clay in an Erlenmeyer flask containing diethyl ether to precipice the polymer. The resultant product was dried under vacuum at $40{ }^{\circ} \mathrm{C}$ for 5 hours. 


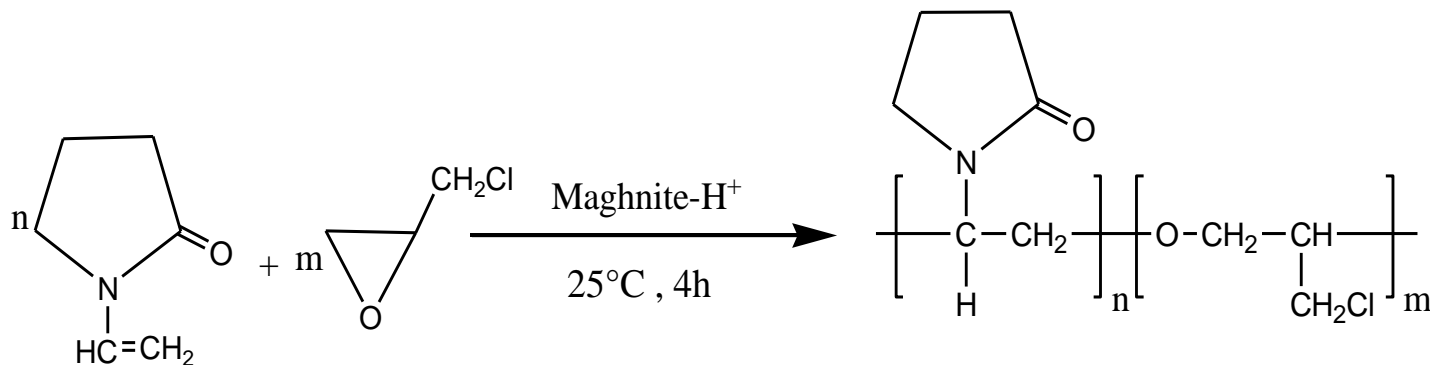

Schema1: Ring opening polymerization of poly (ECH-co-NVP) by Maghnite- $\mathrm{H}^{+}$

Fig3. Shows the FTIR spectra for Poly (ECH-co-NVP) copolymer. A strong absorption at $1702 \mathrm{~cm}^{-1}$ associated with the carbonyl group appears for the copolymers. The characteristic vibration of $\mathrm{C}-\mathrm{O}-\mathrm{C}$ band is observed respectively at $1389 \mathrm{~cm}^{-1}$. A weak absorbance around $3475 \mathrm{~cm}^{-1}$ assigned to the hydroxyl group was observed (KBr), at $2888 \mathrm{~cm}^{-1}$ for $\mathrm{C}-\mathrm{H}$ asymmetric stretching of aromatic structure. The following, at $851 \mathrm{~cm}^{-1}$ for $\mathrm{C}-\mathrm{Cl}$, results may present the preliminary information on such mechanistic aspects of the copolymerization [29].

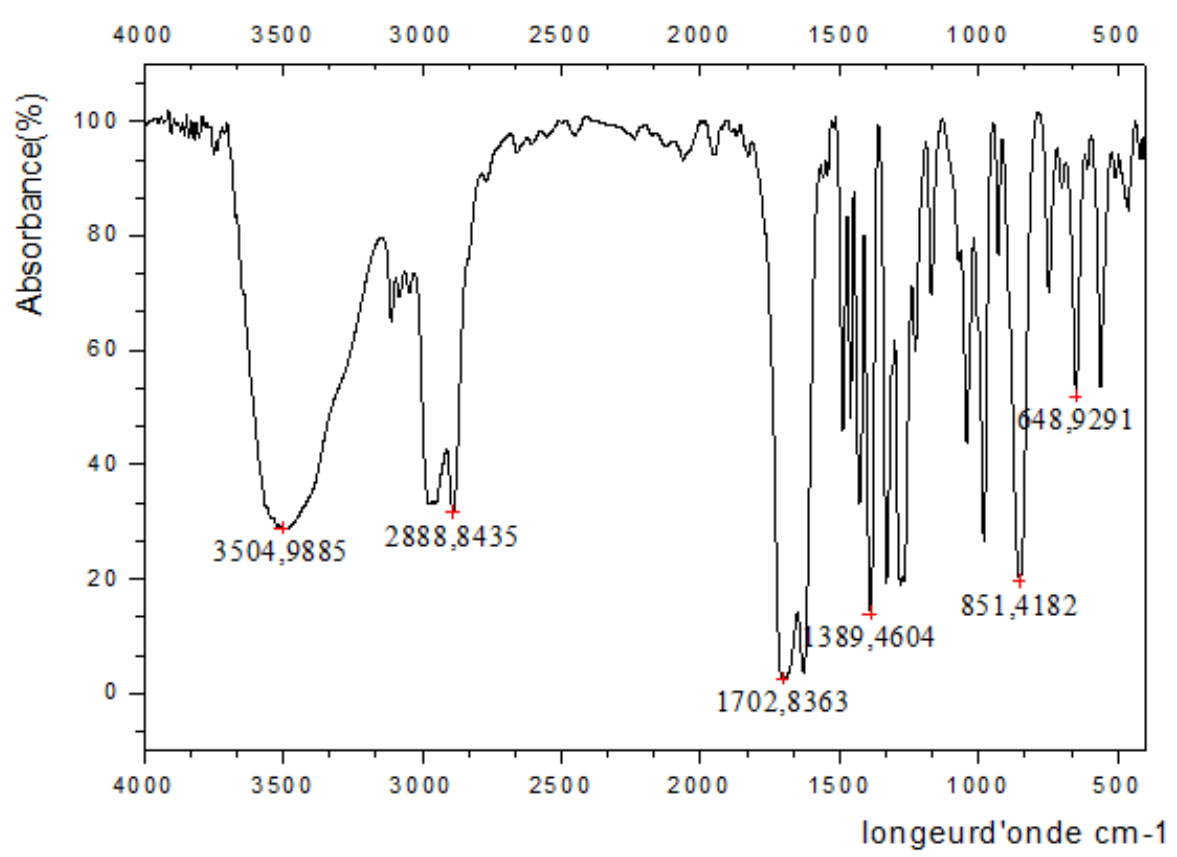

Fig.3: IR spectrum of poly (ECH-co-NVP) polymerized with Maghnite- $\mathrm{H}^{+}$at room temperature.

The copolymer obtained was characterized by $1 \mathrm{HRMN}\left(300 \mathrm{MHz}\right.$, Solvent deuterated $\mathrm{CDCl}_{3}$ ). The different protons observed and their chemical displacements are given in Table 2.On the spectrum 1HRMN (Fig. 4), we also observe a singlet located at about $1.11 \mathrm{ppm}$ which corresponds probably to the methyl of the end of the chain $(\mathrm{g})$. The other protons of the end of chain are confused with the protons of the polymer chain (d, e) at 2.04-2.42 ppm. The proton signals of $-\mathrm{CH}_{2} \mathrm{Cl},-\mathrm{CH}_{2} \mathrm{O}$ and $-\mathrm{CHO}-$ groups are observed respectively at 3.67, 3.50 and $3.45 \mathrm{ppm}$ [30].

\subsection{Kinetics studies}

\subsubsection{Effect of the amount of catalyst $\left(\mathrm{Mag}-\mathrm{H}^{+}\right)$on copolymerization}

Fig5. Shows the effect of the amount of Mag- $\mathrm{H}^{+}$, expressed by using various weight ratios $\mathrm{Mag}-\mathrm{H}^{+} / \mathrm{monomer}$, on the polymerization rate. The polymerization was carried out in bulk. As shown in Figure 5, a yield of 70 wt $\%$ was reached for $10 \mathrm{wt} \%$ of $\mathrm{Mag}-\mathrm{H}^{+}$, and the use of a lower or higher amount of clay caused a decrease of the yield of the reaction. Similar results are obtained by yahiaoui et al. [31]. In the polymerization of Epichlorohydrin, and Ferrahi et al. [32-33] in propylene oxide and cyclohexene oxide by $\mathrm{Mag}-\mathrm{H}^{+}$and the polymerization of styrene by Montmorillonite, respectively. This phenomenon is probably the result of the number of 'initiating active sites' responsible of inducing polymerization, this number is prorating to the catalyst amount used in reaction 


\subsubsection{Effect of temperature on copolymerization process}

The effect of temperature on the copolymerization of N-Vinyl-2-pyrrolidone (4.5g) with Epichlorohydrin (3.71g) initiated by Maghnite- $\mathrm{H}^{+}$(5\% by weight) for 5 hours, is shown in Fig.6. The copolymerization yield reach maximum value around $60{ }^{\circ} \mathrm{C}$. On the other hand, with the increase in the reaction temperature above $60{ }^{\circ} \mathrm{C}$ the molecular weight of the obtained copolymer decrease progressively, suggesting the possible occurrence of thermal degradation [34]. On the basis these results, subsequent copolymerization were carried out at $60^{\circ} \mathrm{C}$

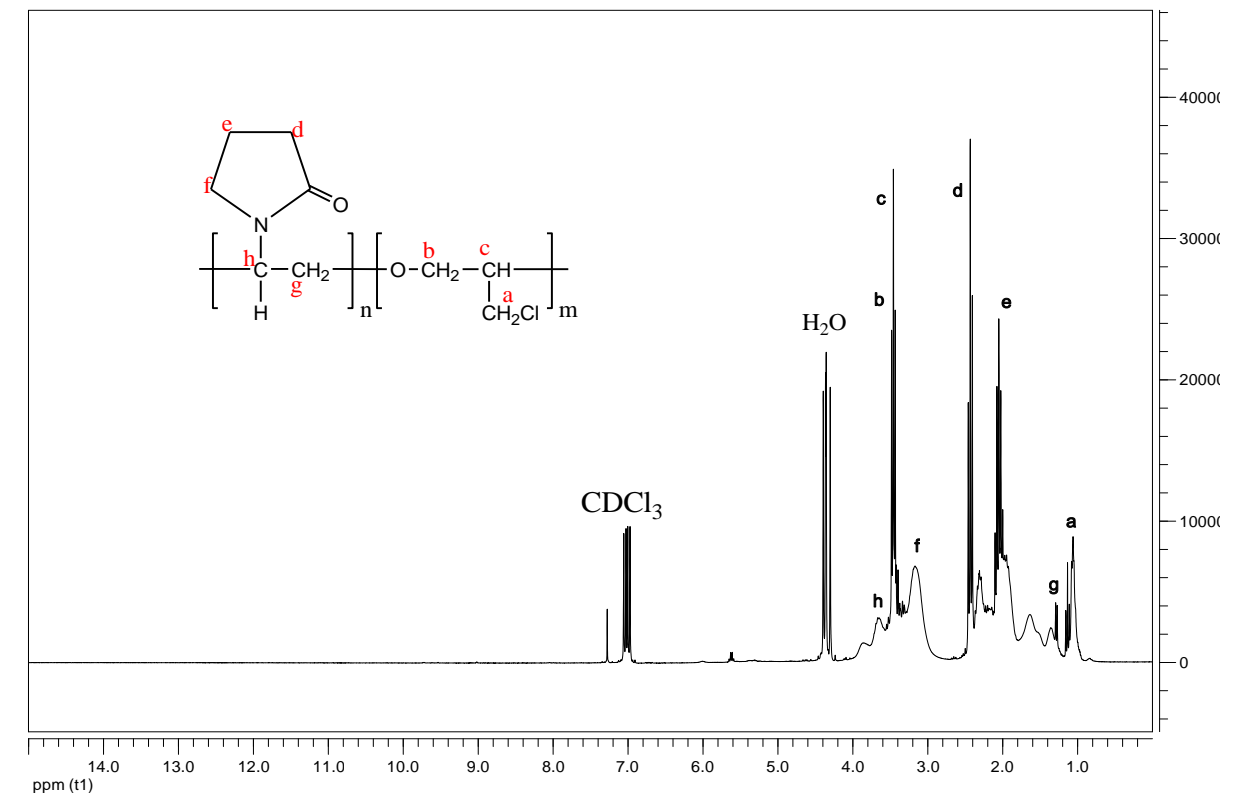

Fig. 4: 1HNMR spectrum of a typical Poly (ECH-co-NVP) in $\mathrm{CDCl}_{3}$ at $25^{\circ} \mathrm{C}$.

Table.2: Chemical shift of copolymers protons

\begin{tabular}{cccc}
\multicolumn{4}{c}{ Table.2: Chemical shift of copolymers protons } \\
\hline protons & \multicolumn{2}{c}{ Déplacements (pmm) } \\
\hline $\mathrm{a}-\mathrm{CH}_{2} \mathrm{Cl}$ & $\mathrm{a}$ & 3.67 \\
$\mathrm{~b}-\mathrm{CH}_{2} \mathrm{O}$ & $\mathrm{b}$ & 3.50 \\
$\mathrm{c}-\mathrm{CH}$ & $\mathrm{d}$ & 2.45 \\
& $\mathrm{e}$ & 2.04 \\
& $\mathrm{f}$ & 3.20 \\
& $\mathrm{~g}$ & 1.11 \\
& & & \\
\end{tabular}

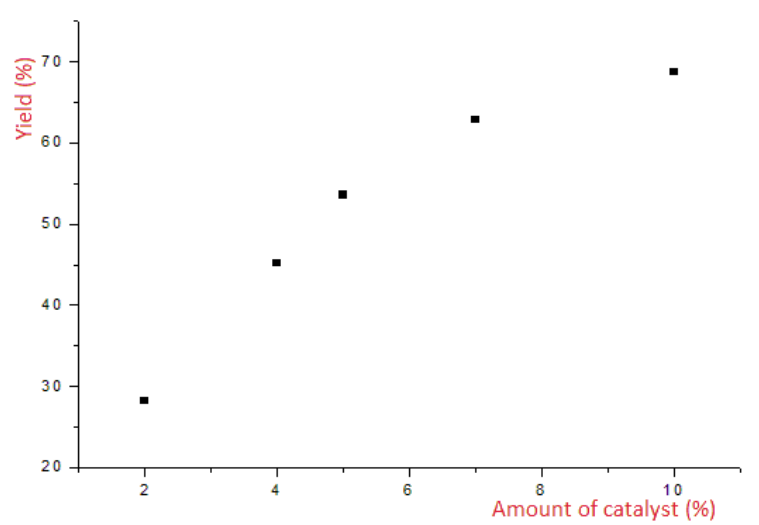

Fig. 5: Effect of the amount on the catalyst on copolymerization of Epichlorohydrin (3,71g), with N-Vinyl-2-pyrrolidone (4,5g). 


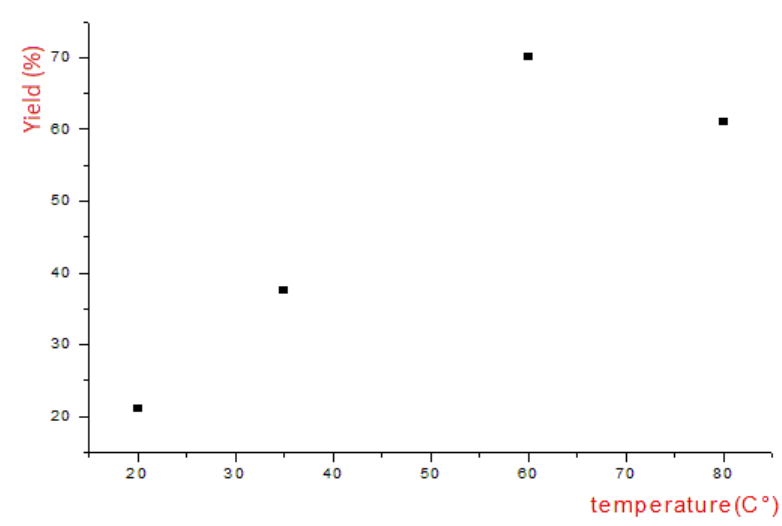

Fig.6: Effect of temperature on the yield on copolymerization of Epichlorohydrin (3,71g), with N-Vinyl-2-pyrrolidone (4,5g).

\section{Conclusion}

The dispersion characteristics of organoclay based on poly (Epichlorohydrin-co-N-vinyl-2-pyrrolidone)Montmorillionite $\left(\mathrm{Mag}-\mathrm{H}^{+}\right)$organoclay were prepared via solution intercalation method. After an extensive study on methods of preparing copolymers, a simple and profitable synthesis of poly (epichlorhydrin-co-N-Vinyl-2-pyrrolidone) copolymers by heterogeneous catalysis have been proposed. The different parameters studied had little influence on the chaining in the copopolymers; it is likely, therefore, that the growing chains are found in a complex form. On the other hand, it is desirable that the synthesis of heterocyclic and vinyl polymers and copolymers by heterogeneous catalysis, initiated by the Maghnite, be followed by larger development, both for fundamental and economic interest that it presents. Finally, the interpretation of structure, morphology and conformation confirms that the resulting product is poly (ECH-co-NVP) by the presence of two motifs ECH and NVP.

\section{Acknowledgements}

We thank all laboratory staff of polymer chemistry from the University of Oran for their kind cooperation.

\section{References}

[1] Georgiev, G.; Konstantinov, C.; Kabaivanov, V.Macromolecules 1992, 25, 6302.

[2] Gao, J. Y.; Dubin, P. L.; Muhoberac, B. B. Anal Chem 1997, 69, 2945.

[3] H. Kamada, Y. Tsutsumi, Y. Yamamoto, T. Kihira, Y. Kaneda,Y. Mu, H. Kodaira, S.-I. Tsunoda, S. Nakagawa, T. Mayumi,Antitumor activity of tumor necrosis factor-a conjugated with polyvinylpyrrolidone on solid tumors in mice, Cancer Res. 60(2000) 6416-6420.

[4] Harper GR, Davies MC, Davis SS, Tadros TF, Taylor DC, Irving MP, Waters JA. Steric stabilization of microspheres with grafted polyethylene oxide reduces phagocytosis by rat Kup!er cells in vitro. Biomaterials 1991; 12:695-9.

[5] Valero V, Buzdar AU, Theriault RL, et al. Phase II trial of liposome-encapsulated doxorubicin, cyclophosphamide, and \#uorouracil as "rst-line therapyin patients with metastatic breast cancer. J Clin Oncol 1999; 17:1425-34.

[6] R.K. Dey, A.R. Ray, Synthesis, characterization, and blood compatibility of copolymers of polyamidoamines and N-vinyl pyrrolidone, J. Appl. Polym. Sci. 90 (2003) 4068-4074.

[7] J.C. Kim, M.E. Song, S.K. Park, et al., Synthesis and characterization of nonionic 1-vinyl-2-pyrrolidinone/methacryloxy silicone copolymers: effects of molecular weight of silicone and crosslinking density, J. Appl. Polym. Sci. 85 (2002) 2244-2253.

[8] X. Lou, K.L. Garrett, P.E. Rakoczy, et al., Synthetic hydrogels as carriers in antisense therapy: preliminary evaluation of an oligodeoxynucleotide covalent conjugate with a copolymer of 1-vinyl-2pyrrolidinone and 2-hydroxyethyl methacrylate, J. Biomater. Appl. 15 (4) (2001) 307-320.

[9] Q. Yang, Z.K. Xu, Z.W. Dai, et al., surface modification of polypropylene microporous membranes with a novel glycopolymer, Chem. Mater. 17 (2005) 3050-3058.

[10] S. Matsushima, A. Takasu, et al., Saturation transfer ratio in magnetic resonance imaging. A novel physical parameter for evaluation of the hydrophilicity of synthetic copolymer gels, Polym. J. 32 (10) (2000) 828-833.

[11] Q. H. Zeng, D. Z. Wang, A. B. Yu, and G.Q. Lu, "Synthesis of polymer-montmorillonite nanocomposites by in situ intercalative polymerization" Nanotechnology, vol. 13,pp. 549-553, Aug.2002.

[12] G. W. Brindley and G. Brown, Crystal Structures of Clay Minerals and Their X-ray Identification, Mineralogical Society, London, 1980.

[13] N. Hasegawa, H. Okamoto, M. Kawasumi, M. Kato, A. Tsukigase, and A. "Usuki. Polyolefin-clay hybrids based on modifiedpolyolefins and organoclay". Macromol. Mater. Engng. Vol. 280/281,pp. 76-79,200.

[14] D. Garcia-Lopez, O. Picazo, J.C. Merino, and J.M. Pastor, "Polypropylene - clay nanocomposites: effect of compatibilizing agents on clay dispersion", European Polymer Journal, vol.39 pp. 945-950, 2002. 
[15] Benharrats, N.; Belbachir, M. Legran, A. P. D’espinose de le Caillerie, J. B. Clays miner.2003,38,49-61.

[16] Breen, C.; Madejovà, J.; Komadel, P. J. Mater.Chem. 1995, 5(3), 496-474.

[17] Belbachir, M ; Bensaoula, A, Composition and method for catalysis using bentonites, US patent, No7, 094-823 B2, 2006.

[18] Ge, H.; Hu, Y.; Jiang, X.; Cheng, D., Yuan, Y.; Bi, H.; Yang, C. (2002) Preparation, characterization, and drug release behaviors of drug nimodipine-loaded poly(epsilon-caprolactone)-poly(ethylene oxide)-poly(epsilon-caprolactone) amphiphilic triblock copolymer micelles.. J. Pharm. Sci. 91: 1463 - 1473.

[19] Albertsson, A.C.; Eklund, M. (1994). Synthesis of copolymers of 1, 3-dioxan-2-one and oxepan-2-one using coordination catalysts. J. Polym. Sci. Part A: Polym. Chem. 32: 265-279.

[20] Storey, R.F.; Mullen, B.D.; Melchert, K.M. (2001). Synthesis of novel hydrophilic poly (ester-carbonates) containing pendent carboxylic acid groups. J. Macromol. Sci. Pure. Appl. Chem. 38:897-917.

[21] Harrane A, Meghabar R, Belbachir M (2002). Cationic ring opening polymerization of glycolide catalysed by a montmorillonite clay catalyst. Int. J. Mol. Sci., 3: 790.

[22] Benahmed A, Ranger M, Leroux J-C (2001). Novel polymeric micelles based on the amphiphilic diblock copolymer poly (N-vinyl-2pyrrolidone)-block-poly (D, L-lactide) Pharm. Res., 18: 323.

[23] S.D. Johnson, J.M. Anderson, R.E. Marchant, Biocompatibility studies on plasma polymerized interface materials encompassing both hydrophobic and hydrophilic surfaces, J. Biomed. Mater. Res. 26 (1992) 915-935.

[24] Farmer,V.C. In Infrared Spectra of Minerals, V.C. Farmer, Ed.; Mineralogical Society: London, 1974, p.331

[25] Moeke, H.H.W. In Infrared Spectra of Minerals, V.C. Farmer, Ed.; Mineralogical Society:London, 1974 , p.365.

[26] Yahiaoui A., Belbachir M., Hachemaoui A.International Journal of Molecular Sciences,2003 4, 548-561

[27] Yahiaoui A., Belbachir M., Hachemaoui A.International Journal of Molecular Sciences, 2003, 4, 572-585.

[28] Benvenuti, F.; Galletti, A. M. R.; Carlini, C.; Sbrana, G.;Nannini, A.; Bruschi, P. Polymer 1997, $38,4973$.

[29] Hong-Quan.X, Shao-Bo.P, Jun-Shi.G, Ring-opening copolymerization of epoxy-terminated polystyrene macromer with epichlorohydrin and study on properties of the copolymers, Eur. Polym. J. 39, 715-724, 2003.

[30] Demirbag, A; Cakmak, I, Synthesis of Epichlorhydrin-Styrene Block Copolymers via Cation-to-Radical Transformation Process, Macromolecular Reports, A33 (SUPPL. 2), 127, 1996.

[31] Yahiaoui A., Belbachir M., Hachemaoui A. An acid exchanged montmorillonite clay-catalyzed synthesis of polyepichlorhydrin. International Journal of Molecular Sciences, 4, 548-561. (2003).

[32] Ferrahi M. I., Belbachir M. Synthesis of cyclic polyesters of poly (oxybutylene oxymaleoyl). Journal of Polymer Research, 12 , 167-171. 2005.

[33] Ferrahi M. I., Belbachir M. Preparation of poly (oxybutyleneoxymaleoyl) catalyzed by a proton exchanged montmorillonite clay. Molecules, 9, 968-977. 2004

[34] Meghabar R., Megherbi A., Belbachir M. Maghnite-H+, an ecocatalyst for cationic polymerization of Nvinyl-pyrrolidone. Polymer, 44, 40974100. 2003. 